\title{
Analysis of Taobao Single's Day Shopping Festival from the Perspective of Managerial Economics
}

\author{
Yufei Quan ${ }^{1}$ \\ ${ }^{1}$ College of Civil Engineering, Northeast Forestry University Harbin, Heilongjiang Province, China, 150036 \\ Author's Email: 1479660537@qq.com
}

\begin{abstract}
With the rapid development of e-commerce, the Internet has affected people's lifestyle habits and shopping methods. In recent years, online shopping has gradually developed into the main shopping channel in people's lives. Various online sales competitions are becoming more and more fierce. In various online marketing, the phenomenon of Taobao Single's Day shopping festival has attracted widespread attention. The scale of Alibaba's Single's Day shopping festival is huge about three times the size of its western counterpart's Black Friday. Since its inception in 2009, it has been playing a pivotal role in (re-)shaping the retail landscape in China. [1]From the perspective of managerial economics, this article analyzes the phenomenon of Taobao Single's Day shopping festival. In addition, the article analyzing the phenomenon from consumer preferences, price elasticity and price discrimination, it also analyzes the influence of externalities on this phenomenon, explains the reasons for the online retail frenzy 'Double Eleven', and better grasps the changes in China's online shopping economy. It further elaborates the importance of management economics for modern enterprise managers in today's increasingly competitive situation.
\end{abstract}

Keywords: Managerial Economics, Taobao Single's Day Shopping Festival, Price elasticity, Phenomenon analysis, PEST Model

\section{INTRODUCTION}

In recent years, online shopping has become a common way to trade information, services and goods. The Taobao Single's Day shopping festival began in 2009 , and every November 11 th, there will be a scene of national carnival. Online consumption is gradually changing the way people consume. In recent years, from 2017 to 2020, the transaction volume of Taobao Mall on November 11th each year was 168.2 billion yuan, 213.5 billion yuan, 268.4 billion yuan, and 467.4 billion yuan. [2] As shown in Figure one, the turnover of Taobao Single's Day Shopping Festival has been increasing year by year, and it has grown rapidly from 2019 to 2020. The surge in this number is amazing. On the one hand, consumers have received preferential treatment, and on the other hand, online shopping malls have developed rapidly. Most of the existing research studies the marketing strategies of online shopping. As mentioned by Li Yiyi, Taobao focuses on product value and marketing strategies from consumer marketing, holiday marketing to pricing marketing.[3] Its Single's Day shopping festival marketing measures are worth learning from the industry. The great success of Taobao on Double Eleven further illustrates that successful marketing strategies are indispensable and can bring real value to enterprises. This article introduces a deeper understanding of consumer preferences, price demand elasticity and discriminatory pricing methods by analyzing the prices and promotion methods of different products, reveals the reasons for the success of the shopping festival, and hopes to be able to influence other e-commerce products, pricing and promotion to bring inspiration and let modern business managers realize the importance of management economics. 


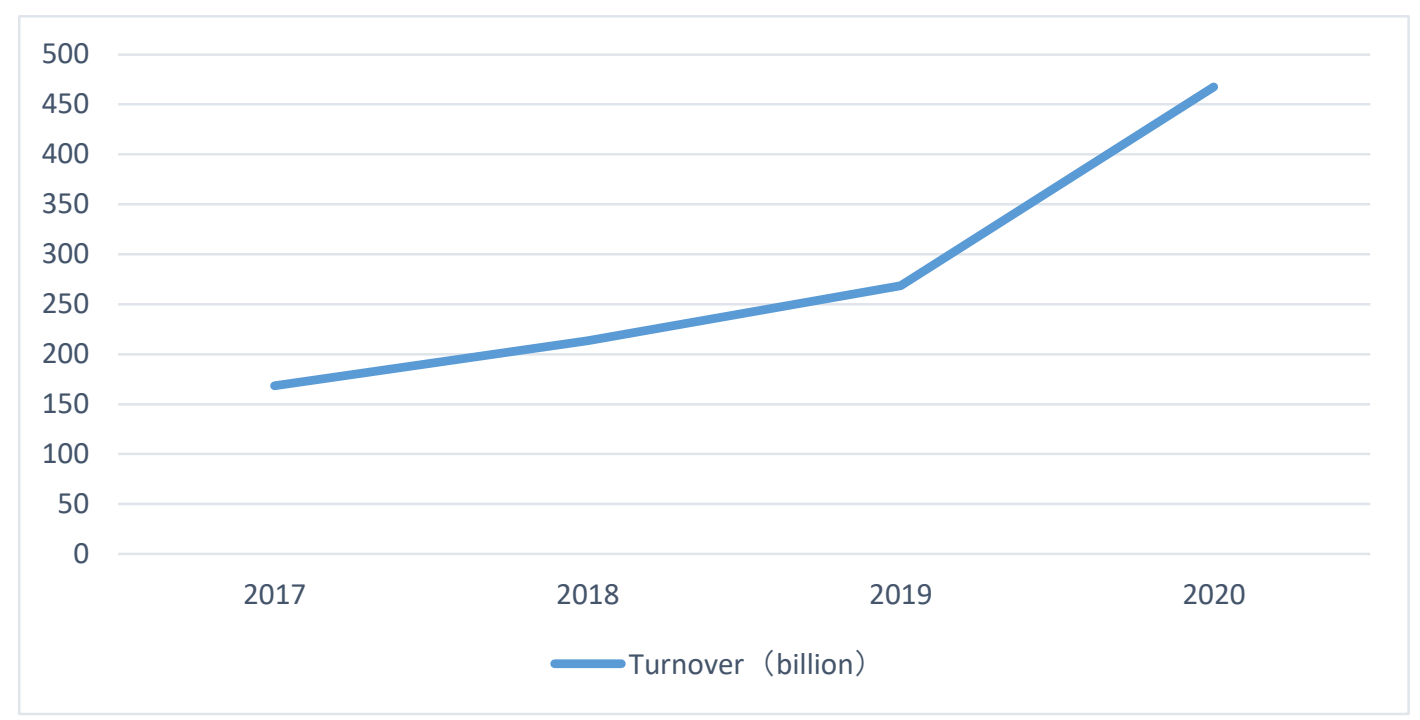

Figure 1. Taobao Single day shopping festival turnover from 2017 to 2020

\section{ANALYSIS OF TAOBAO'S MACRO MARKET ENVIRONMENT WITH PEST MODEL}

\subsection{Analysis of Political Environment}

The development of China's Internet is inseparable from legal constraints. In recent years, China attaches great importance to the construction of Internet laws and regulations. Since the end of 2018, the Standing Committee of the National People's Congress has officially launched the e-commerce law of the people's Republic of China. The e-commerce law regulates the relationship among consumers, businesses and the government through e-commerce channels. The government relies on the law to encourage and support the development of e-commerce, while businesses and enterprises should fulfill all kinds of obligations while enjoying rights.[4] The Chinese government is increasingly concerned about the development of ecommerce. This is conducive to the standardization of ecommerce and the long-term development of ecommerce market.

\subsection{Economic Environment Analysis}

China's economy has shown a sound pattern of stable growth, moderate prices, and a basic balance of international payments. As described by Pan Jiancheng, deputy director of the China Economic Monitoring and Analysis Center, China's economic growth rate has fluctuated slightly within the range of 0.2 percentage points for 12 quarters, which is a phenomenon that has never occurred in history. This also proves that China's economic growth is more resilient, which is also a solid foundation for the high-quality development of China's economy.
In the context of steady economic growth in China, the scale of Chinese netizens has continued to maintain rapid growth. The huge number of Internet users has given the e-commerce field a larger and larger market and more and more development opportunities. At the same time, with the increasing number of entrants in the $\mathrm{C} 2 \mathrm{C}$ and $\mathrm{B} 2 \mathrm{C}$ markets in China and more and more capital investment, the competition has become increasingly fierce. $\mathrm{B} 2 \mathrm{C}$ refers to a retail model that sells products and services directly to consumers in the e-commerce model. $\mathrm{C} 2 \mathrm{C}$ refers to electronic commerce between individuals. The internal competition in the e-commerce industry has produced two results.

On the one hand, the survival of the fittest has been achieved. Some B2C/C2C websites have gradually improved their own governance and services, have provided a good trading environment for both parties, and have had a certain customer base. With the obvious network economic effect, small e-commerce companies are overwhelmed and gradually withdraw from the market, and the e-commerce market gradually becomes mature. On the other hand, competition in the ecommerce market has attracted widespread attention. People have cultivated the habit of online shopping and are increasingly willing to participate in online shopping. These also bring new development opportunities to the B2C and $\mathrm{C} 2 \mathrm{C}$ markets, and bring good development space to Taobao.

\subsection{Social Environment Analysis}

With the application of the Internet, people's reliance on the Internet has increased, and there are more and more Internet users. According to data released by CNNIC, As shown in Figure Two, the number of Internet users in China has reached 940 million in the 2020s, and the Internet penetration rate has reached $67 \%$, a year-on-year 
increase of 10\%.[5] The number of Internet users in China has steadily increased from 2007 to 2020 , and the Internet penetration rate has also increased year by year. The increase of Internet users will inevitably promote the development of China's B2C/C2C e-commerce market. In addition, with the accelerating pace of life, rest time becomes more valuable for people. Therefore, online shopping becomes a new choice for majority.[6]

Online shopping is a change in people's consumption habits. For consumers who are accustomed to traditional contact buying and shopping guide buying, many factors motivate them to make their first online shopping, and the price is a crucial factor. In addition, logistics services associated with online shopping and online payment and other related social supporting services are constantly improving, making online shopping more and more popular, and the number of online shopping continues to increase. Nowadays, e-commerce involves almost all business fields and brings more development opportunities to Taobao.



Figure 2. China's Internet user scale, year-on-year growth rate, and Internet penetration rate from 2007 to 2020

\subsection{Technical Environment Analysis}

Since the 1990s in China, network technology has developed rapidly, and classified search engines have been popularized first. In addition, the invention and promotion of mobile payment, the generation and continuous improvement of third-party payment platform technology (Alipay) and digital certificate security authentication have promoted the transformation of the way consumers interact with online stores, making online shopping more interactive and more interactive. In recent years, new technologies in e-commerce such as networking, big data, and cloud computing have also played a key role in the development of the e-commerce industry.

\section{ANALYSIS OF CONSUMER PREFERENCE}

The abundance of goods directly affects the competitiveness of e-commerce companies. Alibaba has taken the lead in introducing cloud computing technology among many e-commerce companies using big data to analyze consumer preferences so that users can accurately search for themselves in a large number of products.

Cloud computing technology has powerful data analysis capabilities and can obtain consumer preferences through consumer search records and purchase behavior. Using the analysis function of big data can not only enable sellers to understand the market, customers and their products more accurately, but also enable buyers to make more timely decisions. The real-time nature of big data analysis shortens the time for sellers to make decisions, and also enables products to be produced and sold faster. In the current competitive market environment, high efficiency can attract more customers to make faster decisions. In addition, in the era of big data, businesses can use massive data to analyze economic behavior and determine the latest developments, so as to achieve early intervention and analysis of new things, which is forwardlooking. This kind of forward-looking can be used to predict industry trends and other information that has a profound impact on the company. During the "Double Eleven" period, Taobao sellers intuitively understand consumer preferences through big data technology and choose the most appropriate marketing plan for their products. 
And Taobao also launched a pre-sale campaign before "Double Eleven", where consumers can pay a deposit first and then make up the balance after a period of time. The implementation of the pre-sale model is actually a manifestation of the $\mathrm{C} 2 \mathrm{~B}$ business model. There are sales orders first, production is carried out, transportation after production, circulation to the market after transportation, and finally sales are realized. With the pre-sale model, sellers can understand consumer preferences in advance, which helps sellers prepare goods in advance and accurately locate them.

\section{ANALYSIS OF PRICE ELASTICITY OF DEMAND}

The price elasticity of demand is generally used in economics to measure how the quantity of demand changes with changes in the price of commodities.[7] Demand elasticity is greater. The elasticity of demand is the degree to which the change in the quantity of demand affects the price change.

It is expressed by the formula as $\mathrm{Ed}=(\triangle \mathrm{Q} / \mathrm{Q}) /(\triangle$ $\mathrm{P} / \mathrm{P})$, and the large demand elasticity means that when the price of a commodity drops, and it will lead to a large amount of demand.[8] Most daily necessities such as edible oil, rice, and toilet paper lack elastic demand. Conversely, the price elasticity of demand for nonnecessities such as clothing, shoes and bags, and electronic products is greater than that of other types of products. From the perspective of Taobao Double Eleven sales in 2020, most of the businesses with sales of more than 100 million are electrical brands, such as Apple, Midea, Huawei, Haier, Xiaomi. There are also a small number of clothing brands, such as Adidas, Uniqlo, and Nike. Therefore, people's demand for such commodities is more likely to be affected by prices. The original price of this kind of goods does not fluctuate much within a certain period of time, and the price difference in different regions and stores is not big, so they use the "Double Eleven" price reduction promotion to attract consumers.

\section{ANALYSIS OF PRICE DISCRIMINATION}

In addition to the most commonly used discount coupons, rebates, points and other promotional methods, Taobao also has a variety of new methods, such as prepaid deposits, team mode, and this year Alipay cloud raising cats to share red packets. The time of the rich is more precious, and the cost of time is higher. However, the cost of time is lower for the poor. The rich mostly choose to buy directly because they are afraid of wasting time, and the poor will spend time studying how to save money, thus realizing price discrimination. At the same time, people from all walks of life are attracted to participate in the shopping festival. In addition, the more products consumers buy, the lower the price of the product. Although prices will fall, businesses have increased production, achieved economies of scale, and can still increase profits. At the same time, low prices will attract more consumers.

\section{CONCLUSION}

With the rapid development of network information technology, more and more people have become Internet users, and online shopping has become a mainstream shopping method. Taobao "Single's Day Shopping Festival" has a good development prospect. Taobao Single's Day Shopping Festival brings consumers a better consumer experience. It brings huge growth in consumption levels to the country, and the future of the ecommerce industry will have unlimited development momentum.

Taobao "Single's Day Shopping Festival" promotion is not a simple act of price reduction. Through the analysis of the successful phenomenon of Taobao "Single's Day Shopping Festival", people can understand the management economics methods used by Taobao, such as consumer preference theory, the theory of price elasticity of demand and the theory of price discrimination have played a vital role in the success of the "Single's Day Shopping Festival" event. The theories of management economics have a huge impact on the development of the e-commerce industry. These theories are also applicable to other e-commerce platforms and companies. Therefore, business managers in contemporary society should cultivate the ability to analyze and solve problems from the perspective of management economics, establish a way of thinking based on management economics to make management decisions, and make scientific and feasible plans through rational thinking.

\section{ACKNOWLEDGMENT}

Thanks for teachers, who are wise, kind, patient and tolerant. They provided valuable ideas and guidance when choosing topics in the early stage of my thesis and writing in the mid-term. Among them, the professor who taught me the subject of marginal economics gave me great inspiration and expanded my academic vision, these will be precious treasures that will accompany me throughout my life. Sincere thanks to all the teachers for their help.

\section{REFERENCES}

[1] Yang, J. Y. (2020). A Pricing Perspective on Double Eleven. The Pricing Puzzle.

[2] Zhicheng Finance and Economics.(2020).Turnover of Taobao Single's Day shopping carnival over the years Taobao Single's Day sales summary over the years.Retrieved from http://www.zhicheng.com/cjzx/n/351977.html 
[3] Li Y., Ma C., Huang C., Dilihumar Y., Jiang Z., \& Jiang J. et al. (2019). Taobao "Double Eleven Shopping Festival" marketing strategy analysis. Modern Business, 000(031), 1617.doi:CNKI:SUN:XDBY.0.2019-31-006

[4] Yang C., Bao Z., Yang J., \&amp; Li C.. (2019). With the formal implementation of e-commerce law, where will e-commerce go in the future. Computer system network and telecommunications, 1 (1), 1315. Doi: $10.18686 / j$ jjxt.v1i1.93

[5] China Internet Information Center.(2021).China's Internet user scale, year-on-year growth rate, and Internet penetration rate.Retrieved from https://www.fxbaogao.com/dt?keywords=\%E4\%B 8\%AD\%Е5\%9B\%BD\%E4\%BA\%92\%E8\%81\%94 $\%$ E7\%BD\%91\%E7\%94\%A8\%E6\%88\%B7\&order $=2$

[6] Zhao, J. , Liu, H. , Xue, W. , \& Koch, S. . (2019). Pest embedded swot analysis on china's e-commerce industry development strategy. Journal of Electronic Commerce in Organizations (JECO), 17(2),55-

68.doi:10.4018/JECO.2019040105

[7] Gao H. .(2014) Western Economics: Microeconomics: 6th Edition. Beijing: Renmin University of China Press.

[8] Li Z.. (2018). Economic analysis of Alibaba's "Double Eleven" shopping carnival phenomenon. Bohai Rim Economic Outlook, 2018 (04), 165-167. doi:10.16457/j.cnki.hbhjjlw.2018.04. 110. 